\title{
Krestanské hagiografie (Život Márie Egyptskej, Život Margity/Mariny Antiochijskej) a texty tzv. jarného vynášania smrti (Moreny, Mařeny, Marzany) u západných Slovanov. Pokus o paralelné čítanie
}

\author{
Martin Golema
}

The study builds on research and interpretation of texts of the so called "death (Morena, Marena, Marzana) carrying-out in spring" among the western Slavs. The author tries to examine an assumption about the existence of a "chemically almost pure" Slavonic mythology goddess embodying death in texts about death carrying-out in spring. He tries to prove that it is a hybrid text unit originating in several text traditions, both in the identified Christian (Byzantine) text store and in early Slavonic myths.

V poslednom čísle Studia mythologica Slavica (Łuczyński, 2008) bol publikovaný velmi systematický výklad textov tzv. jarného vynášania smrti (Moreny, Mařeny, Marzany) u (predovšetkým západných) Slovanov. Zistenia synteticky zhrnuté v tejto štúdii chceme spresnit’ v jednom bode, pokúsime sa dokázat', že ide o hybridný textový útvar vyrastajúci z viacerých textových tradícií, vyrastajúci zároveň z identifikovatelného krestanského textového fondu i z praslovanských mýtov. Pokúsime sa zásadnejšie revidovat' predpoklad, že v textoch jarného vynášania smrti máme dočinenia s „chemicky takmer čistou“ bohyňou slovanskej mytológie stelesňujúcou smrt, zviazanou so sezónnymi rituálmi odumierania a ožívania prírody a s rituálmi privolávania dažda. ${ }^{2}$ Chceme dalej ukázat', že táto mytologická postava do seba vstrebala a okolo seba sústredila stále identifikovatelný textový materiál pochádzajúci vel’mi pravdepodobne $\mathrm{z}$ oficiálnych legendových látok o kajúcničke sv. Márii Egyptskej a o martýrke sv. Margite/Marine Antiochijskej, v texte sú zároveň prítomné aj významné rezíduá tzv. Mokošinho textu.

Texty štrukturálne výrazne analogické so zachovanými variantmi textov jarného vynášania smrti možno nájst’ v byzantskom hagiografickom fonde. Geografické rozšírenie zvyku jarného vynášania smrti zahŕňa práve tú čast’ strednej Európy v 9. až 11. storočí zasiahnutú grécko-slovanskou kultúrou, ktorú Dvorník (2008, s. 142) nazýva Sclavinia, zahŕňa teda západných Slovanov, sčasti aj susediace nemecké oblasti, J. Grimm (1968, s. 629-658) ho však považuje za slovanský zvyk. Medzi Mad’armi južná hranica výskytu zvyku „kiszehajtás“ - vynášania kysela (Moreny) prevzatého od Slovanov - siahala na juhu skoro až po čiaru Budapešti (Manga, 1956). Uvažuje sa o presnejšie nedatovanom stredovekom pôvode zvyku, ktorý predstavuje syntézu „ludovej mágie a rustikalizovanej krestan-

\footnotetext{
Štúdia vznikla v rámci riešenia grantu Vedeckej grantovej agentúry MŠ SR a SAV č. 1/0583/08.

2 Takto ju definuje napr. Ivanov - Toporov (1987, s. 111).
} 
skej ideológie“ (Slivka, 1992, s. 56). Na tento názor chceme nadviazat’ a bližšie ho spresnit', sformovanie rituálu datovat’ už do čias Vel'kej Moravy a jeho šírenie, etablovanie a pretrvávanie vysvetlit dočasne birituálnym prostredím českého biskupstva, Pol'ska i Uhorska.

Ako správne upozornil Manga (1956, s. 432), už najstarší známy zákaz českej synody z roku 1366, zmieňujúci sa o účasti kňazov pri vynášaní smrti, podporuje domnienku, že tento zvyk už dávnejšie alebo ešte i v čase zákazu prináležal alebo bol blízky cirkevnej liturgii. ${ }^{3}$ Další výskum ustrnul pri podobných konštatovaniach a z tohto „mŕtveho bodu“ sa zatial" neposunul (aspoň nám to nie je známe) k žiadnym evidentne „podozrivým“ partiám dobovej západnej (rímskej) liturgie, z ktorých by boli texty vynášania smrti priamo odvoditelné. Nazdávame sa, že sme identifikovali hlavnú príčinu tohto ustrnutia, doterajšie úvahy chybne predpokladali nepretržitú dominanciu rímskej, latinskej cirkvi v skúmanom priestore stredovekej Sclavinie a zabúdali na to, že uvedený priestor bol v 9. až 11. storočí biliturgický, že teda bol pod významným byzantským vplyvom a že je teda nutné nanovo prezriet’ a zohladnit’ aj dobové byzantské liturgické zvyklosti. Ak to spravíme, otvorí sa možnost' hladat' liturgické korene aj v liturgických zvyklostiach byzantskej cirkvi a tu môžeme vzápätí narazit na už spomenutý velmi nádejný zdroj textov jarného vynášania smrti, na legendu Život Márie Egyptskej.

Pred analýzou textu tejto legendy a následnou komparáciou (paralelným čítaním) s textom jarného vynášania smrti bude užitočné aplikovat známy štrukturalistický postulát, podla ktorého hodnotu svätice určuje jej pozícia v systéme „všetkých svätých“ daného kultúrneho okruhu (tento systém sa premieta do liturgie). Bolo by teda neproduktívne skúmat’ sv. Máriu Egyptskú ako izolovaný prvok, treba sa zamerat’ na vejár vlastností, ktoré ju odlišujú od iných svätých v konkrétnom kultúrnom okruhu, treba si všímat jej hierarchickú pozíciu v konkrétnom systéme. V latinskom kultúrnom okruhu ide o radovú až periférnu sväticu, na čo ukazuje napr. redukovaná (oproti byzantskej pôvodine) dĺžka jej legendy v zbierke Legenda Aurea (Legenda na dzień św. Marii Egypcjanki, 1983, s. 201-206), v západnom liturgickom kalendári je jej zasvätený iba jeden z bežných dní - 2 . apríl. V byzantskom kultúrnom okruhu sú jej zasvätené až tri sviatky, okrem 2. apríla ešte štvrtok piateho týždňa Velkého pôstu (vtedy sa v rámci liturgie číta jej Život, a to jeho byzantská pôvodina, tá je oproti skráteným latinským verziám podstatne dlhšia, Život je navyše rámcovaný rozsiahlym Velkým kánonom sv. Andreja Krétskeho (Velký kánon, online) a spolu s Vel'kým kánonom tvorí súčast’ významnej liturgickej knihy, tzv. Pôstnej triody. ${ }^{4}$ Márii Egyptskej je zasvätená aj 5. nedela Velkého pôstu (Nedel’a prepodobnej mat-

\footnotetext{
3 Uznesenie tejto synody hovorí: „....kedže sa v niekolkých mestách, hradoch a miestach u kňazov a svetských ludí zakorenil nesprávny zvyk, že uprostred pôstu za poverčivých spevov a obradov nesú cez mesto k rieke figúry zobrazujúce smrt’ a tam ich prudko ponoria do vody, tvrdiac na ich pohanenie, že smrt' už nemôže škodit', lebo ju z chotára vyhubili a do koreňa vykynožili..." (Manga, 1956, s. 431). Najstarší zachovaný cirkevný zákaz jarného vynášania smrti hovorí teda o účasti kňazov a o praktikovaní zvyku v politických a kultúrnych centrách (hradoch, mestách ) - teda nie na periférii, vidieku. Domnievame sa, že českej cirkvi v roku 1366 nešlo len o likvidáciu pohanských povier, ale aj o likvidáciu zdá sa velmi populárnych a tvrdošijne odolávajúcich pozostatkov grécko-slovanskej kultúry, ktoré už v zmenených pomeroch nemali liturgickú oporu.

4 Autorom Velkého kánonu, pozoruhodného a v pravoslávnej liturgii stále živého diela, bol sv. Andrej Krétsky, biskup na Kréte (660-740). Ako celok sa text Velkého kánonu spieva vo štvrtok v 5. týždeň Velkého pôstu, pred ním je čítaný Život sv. Márie Egyptskej. V Kánone sú začlenené opakované prosby k Márii Egyptskej, kánon je ilustrovaný čítaním jej Života, pridáva k Životu rozsiahly poetický komentár, je teda s touto legendou nerozdelitelne zrastený. Mária Egyptská je aj vd’aku nemu výraznou dominantou 5. pôstneho týždňa vo východnej cirkvi. Slovanský preklad Vel'kého kánonu „vznikl velice brzy, již v 9.-10. století. Nelze však říci, zda lze překlad vztáhnout ještě k velkomoravskému období, protože neexistují potřebné podklady" (Milko, 2005, s. 65).
} 
ky Márie Egyptskej (Triodion, 2004, s. 5)), v systéme východných svätých premietajúcom jej kult do až troch sviatočných dní sa teda Mária Egyptská teší podstatne väčšej úcte ako jej západný náprotivok.

Pevné usadenie (načasovanie) rituálu jarného vynášania smrti v liturgickom roku (predovšetkým 5. nedela Vel'kého pôstu, tzv. „smrtná nedela“) odkazuje práve na dávnu spojitost’ s liturgiou. ${ }^{5}$ Ak skúmame liturgické zvyklosti západnej cirkvi, nič, z čoho by boli odvoditelné významné časti skúmaných textov, v západnej liturgii nenachádzame. Nádejnejšie, ba velmi nádejné je pátranie v liturgii východnej cirkvi - zaujímavé a nie náhodné je, že v smrtnú nedelu si východná cirkev pripomína práve pamiatku spomínanej sv. Márie Egyptskej, vo východnej tradícii mimoriadne významnej kajúcničky stelesňujúcej hodnoty pôstu a pokánia. V jej biografii zaujmú dve výrazne odlíšené etapy osudu, najprv vel’mi hriešna mladost’ v Alexandrii, potom radikálne obrátenie v Jeruzaleme a následné prísne pokánie, pôst a smrt’ v jordánskej púšti. Tejto textovej stope sa teraz chceme podrobnejšie venovat'.

Legeda (opakovane čítaná a rozsiahlo komentovaná v liturgii 5. týždňa Velkého pôstu) Život Marie Egyptské, někdejší nevěstky, konající př́isné pokání v Jordánské poušti (Byzantské legendy, 2007, 83-95) bola napísaná v 7. storočí, autorstvo je pripisované Sofróniovi I. (634-644), jeruzalemskému patriarchovi. Legenda sa v úvode obsiahlo zmieňuje o zvláštnych pôstnych praktikách palestínskych mníchov (úvod možno čítat aj ako akúsi mníšsku regulu vo forme rozprávania ${ }^{6}$ ), mnísi na začiatku Vel'kého pôstu prešli rieku Jordán a rozptýlili sa po púšti zásobení malým množstvom potravy zodpovedajúcej (podla prísnejšieho východného úzu zakazujúceho nielen mäso, ale aj vajcia a mlieko) obdobiu pôstu (vymenúva sa tu chlieb, sušené ovocie - figy a datle, máčané a naklíčené bôby (šošovice? hrachy?)), niektorí si vzali iba potrhaný odev a svoje telo sýtili iba trávami rastúcimi na púšti.

Z púšte sa vracali až na Kvetnú nedelu (podla východného úzu vtedy končil Velký pôst), obdobie pôstu trávili v samote. Jeden z mníchov, starec Zosima, ktorý už prešiel všetkými stupňami askézy, ale stále túžil stretnút niekoho, kto by bol v askéze dokonalejší

Vel'ký kánon je súčastou tzv. Pôstnej triódy, bohoslužobnej byzantskej knihy obsahujúcej texty velkopôstneho obdobia. Ako uvádza Marinčák (2005, s. 50) „počas „účinkovania bratov Konštantína a Metoda existovalo 8 druhov kníh konštantínopolskej tradície, ktoré mohli byt' preložené do slovanského jazyka: profetologion, euchologion, horologion, oktoechos, apoštol, evanjeliár, menologion a žaltár. Miguel Arranz pridáva ešte deviatu knihu, akýsi prvý náznak knihy triodion, dielo Kozmu Majumského (biskup od r. 743, zomrel roku 760) d’alej rozvíjané Teodorom Studitom (759-826) a jeho bratom Jozefom (760/2-832).“

Slovanský preklad byzantskej liturgickej knihy Triodion (obsahujúcej liturgické texty na čas Velkého pôstu, teda aj Vel'ký kánon) bol v slovanskom prostredí používaný už koncom 9. a v 10. storočí, vyplýva to z gréckeho Vita bulharského arcibiskupa a žiaka Konštantína a Metoda, Klimenta Ochridského (830-916). V ňom sa uvádza, že pred smrtou Kliment preložil tzv. Kvetnú triodu (Pentekostarion), liturgickú knihu, ktorá priamo nadväzovala na Pôstnu triodu. Z tohto textu teda vyplýva, že slovanská Kvetná trioda bola používaná niekedy od r. 916, Pôstna trioda (a teda aj Velký kánon a Život Márie Egyptskej) musela byṫ používaná v slovanskom prostredí už skôr, niektorí bádatelia (G. Popov) sa domnievajú, že uvedené obidve liturgické knihy preložili už Konštantín a Metod pre potreby moravskej cirkvi (Triodion, 2004, s. 113-114).

Korene stredovekej drámy treba hladat v „chráme... a v určitých partiách liturgie“ (Černý, 1964, s. 14).

6 Najstaršia uhorská legenda Život svätých pustovníkov Svorada vyznávača a Benedikta mučeníka, napísaný od Maurusa, pätkostolského biskupa (vznikla 1064-1070, Svorad zomrel okolo r. 1031) dokazuje, že pustovník, nitriansky benediktín Svorad, inšpirujúci sa v mnohom asketickými praktikami palestínskych pustovníkov, dôverne poznal neskrátenú (byzantskú?) verziu textu Život Mária Egyptskej, pridŕžal sa totiž dôsledne pôstnych zvyklostí detailne priblížených práve v Živote Márie Egyptskej, text legendy ich priamo nazýva aj „regula Zosimi“" (Legendy stredovekého Slovenska, 1997, s. 33-43, 345-348). 
než on sám, po 20 dňoch cesty púštou zbadal neznámeho človeka. Ten „byl nahý a kůži měl tmavou, jako by ho spálil sluneční žár, a vlasy měl bílé jako rouno "(Byzantské legendy, 2007, s. 86). Ked' ho Zosima dostihol, delilo ich vyschnuté koryto rieky. Zosima zistuje, že je to úplne nahá žena, daruje jej preto polovicu svojho plášta.

Neznáma (oslovuje ju matka ${ }^{7}$ ) mu po dlhšom naliehaní rozpovie svoj príbeh. Zosima sa dozvedá, že v mladosti 17 rokov ako pobehlica v Alexandrii kupčila so svojím telom, nie však kvôli peniazom, bezplatne robila iba to, po čom bezuzdne prahla. Nebola pritom bohatá: „...stávalo se mi, že jsem musela prosit o milodary nebo si vydělávat předením $^{8}$ - ale byla jsem zachvácena nenasytnou a nezadržitelnou touhou" (Byzantské legendy, 2007, s. 88). Raz sa pridala k davu pútnikov plaviacich sa lod’ou do Jeruzalema na sviatok Povýšenia svätého kríža, odhodila svoje vreteno („někdy jsem je nosila s sebou“) a bežala k moru za náhliacim sa davom. Počas plavby sa mužskí členovia posádky stali obetou jej telesnej túžby: „K čemu jsem ty neštastníky ponoukala, dokonce i proti jejich vưli! Neexistuje žádná neřest, at už popsatelná nebo nepopsatelná slovy, ve které bych já nebyla učitelkou těch neštastníkü. Divím se, otče, že moře vydrželo moji prostopášnost, že země neotevřela své útroby a zaživa mne nepohltila, když jsem vtáhla do svích sití tolik duši" (Byzantské legendy, 2007, s. 89).

Na sviatok Povýšenia sv. Kríža v Jeruzaleme ju tajomná sila nevpustila do chrámu, po troch ba štyroch neúspešných pokusoch budúca kajúcnička pochopila, prečo nemohla uvidiet’ „životodarné drevo kríža“, príčinou bola nemravnost' jej činov. Pred ikonou Bohorodičky slúbi: „... již nikdy více neposkvrním své tělo hanebním stykem, vždyt’ sotva pohlédnu na dřvo křiže syna tvého, ihned se zřeknu tohoto světa a všeho světského a ihned odejdu, kam mi ty, záruko mého spasení, přikážeš, a kam mne povedeš“(Byzantské legendy, 2007, s. 90). Po tomto slube vstupuje do chrámu chvejúc sa po celom tele, a uzrie „sväté tajomstvá“. Začína nová, ostro odlíšená etapa jej ženského osudu, vychádzajúc z chrámu počuje z dialky hlas: „Přejdi Jordán a dojdeš blahého klidu“. Pri východe z chrámu jej ktosi dá tri medené mince, za ne si ona kúpi tri chleby a vezme si ich na cestu „jako eulogii." ${ }^{\text {" }}$

Kajúcnička prichádza k chrámu sv. Jána Krstitela pri Jordáne, po modlitbe vstúpi do Jordánu a skropí si „posvátnou vodou obličej a ruce ${ }^{\text {“10 }}$, potom v chráme Predchodcu pána prijme „čisté a životodarné svátosti“ (eucharistiu), zje polovicu jedného so svojich troch chlebov-eulogií a napije sa vody z Jordánu. ${ }^{11}$

\footnotetext{
7 Matka (amma) alebo otec (abba) bol niekto, kto dosiahol vysoký stupeň zrelosti a múdrosti, bol zbehlý vo vyučovaní prostredníctvom vlastného príkladu, kázní, príbehov, výrokov a povzbudení (Olexák, 2007, s. 63).

8 Pradenie (teda i vreteno) ako atribút úzko spája Máriu Egyptskú a praslovanskú bohyňu Mokoš.

9 Eulogia, antidóron - je vo východnej tradícii požehnaný kvasený chlieb, ktorý sa rozdáva veriacim po liturgii pri odchode z chrámu „anti tón hagión dórón“, „pro donis sacris“, tj. namiesto eucharistie alebo na jej pripomenutie. V byzantskej liturgii sa na tento účel používajú nekonsekrované prosfory, nepoužité pri proskomidii (kňaz sa dotýka týmito chlebami kalicha). Eulogie sa rozdávajú aj v dalších orientálnych cirkvách; tiež západná cirkev poznala túto prax, aj ked' nie ako náhradu eucharistie, ale len ako znamenie božieho požehnania, a to $\mathrm{v}$ oblasti galikánskej a mozarabskej (Francúzsko a Španielsko) (Byzantské legendy, 2007, s. 253).

${ }^{10} \mathrm{Na}$ otázku, kde prebývala, folklórna Morena dáva často odpoved’ typu: „Při Dunaju, při mořu, nožky umývala; U voděnky, ruky sem si myla" (Łuczyński, 2008, s. 182).

${ }^{11}$ Text legendy takto ustanovuje pevné syntagmatické (skôr priestorové ako temporálne) puto medzi Máriou a sv. Jánom Krstitelom, Mária sa rituálne umýva v Jordáne pri chráme sv. Jána Krstitela, obnovujúc tak krst pokánia v tejto rieke ustanovený sv. Jánom, ktorému sa podrobil aj Ježiš, prijíma v jemu zasvätenom chráme eucharistiu, zdržiava sa v púšti, v ktorej žil Ján Krstitel'. Toto pevné syntagmatické spojenie dalej pretrváva aj v kontinuantoch textu, čo vysveluje občasnú prítomnost' sv. Jána v textoch vynášania smrti a zase naopak, prí-
} 
Následne sa preplaví na druhý, neobývaný a pustý breh rieky, kde do stretnutia so starcom Zosimom žije osamote a v prísnej askéze celých 47 rokov. Z toho prvých 17 rokov bojuje so sexuálnou túžbou, túži aj po mäse a egyptských rybách, po víne, ktorého predtým „mnoho vypila“, na púšti však nemá ani vodu a nevýslovne trpí smädom. Živí sa spomenutými dva a pol chlebami-eulogiami, ked' ich zje, živí sa „trávami a vším, co jsem mohla na poušti najít. "12 Šaty sa jej postupne rozpadli, vyvstáva tu protiklad: šaty (pradenie, vreteno) a po kajúcnom obrátení nahota implikujúca zákaz priast' (odhodenie vretena pred nastúpením na lod' smerujúcu do Jeruzalema), $\mathrm{k}$ hladu a smädu ${ }^{13}$ sa tak pridáva aj d’alšie utrpenie: „Velmi často jsem strádala chladem i letním žárem; spalovalo mne slunce, nebo mé ztuhlé údy roztřásala zima, takže jsem často klesala k zemi a ležela nehybně a téměr bez dechu. Neustále jsem se střetávala s úklady a děsnými pokušeními d’ábelskými“(Byzantské legendy, 2007, s. 92).

Na záver stretnutia kajúcnička Zosimu požiada, aby na budúci rok v čase Velkého pôstu neprešiel Jordán, ako je u nich v kláštore zvykom (prorocky podotkne, že aj keby chcel, nebude môct', Zosimu skutočne v tento čas zachváti zimnica, ${ }^{14}$ a preto nemôže opustit’ kláštor). Požiada ho, aby presne v deň „svaté večeře Páně“ (v Zelený štvrtok) v tú istú hodinu, v ktorej Pán „sezval učedníky ke svaté večeři “vzal v posvätených nádobách „tělo a krev Kristovu“ (vo východnom úze kvasený chlieb a víno), čakal „na tom břehu Jordánu, který je bliž k osadám" (Byzantské legendy, 2007, s. 92) a umožnil jej prijat’ sväté dary. Od čias, ako opustila kláštor sv. Jána Krstitela, totiž neprijímala eucharistiu. Po týchto slovách kajúcnička opät odišla do púšte, neprezradiac mu ani svoje meno.

Zosima jej prosbu splní, rok po tomto stretnutí v súlade s proroctvom kajúcničky nemôže kvôli zimnici opustit’ v dobe Vel'kého pôstu kláštor. Ked’ sa ostatní mnísi vrátia z púšte a ked’ nadíde deň „večeře Páně“, urobí to, čo mu neznáma prikázala. Do malého pohárika vezme „nejčistši tělo a ctihodnou krev" Ježiša Krista, naviac si vezme aj košík ${ }^{15}$, v ktorom sú „fíky, datle a něco máčených fazoli“"16, neskoro večer opustí kláštor a posadí sa na breh Jordánu, aby vyčkal na príchod svätice. Obáva sa toho, ako svätica prejde rieku (nablízku nie je žiadna lodkka). Za jasnej noci ju zazrie na protilahlom brehu. Kajúcnička urobí nad Jordánom znamenie kríža, vstúpi na hladinu a suchou nohou kráča po vode ${ }^{17}$ k nemu. Starec si pri pohlade na ňu uvedomí, ako d’aleko má k dokonalosti on sám napriek tomu, že je vzorový mních. Na jej výzvu sa pomodlí, ked’ skončí modlitbu, ona „podle

tomnost' Mary, Mareny pri kupalských obradoch v deň sv. Jána (podobnosti kupalských obradov a vynášania smrti analyzuje Tolstaja (online)). Syntagma Ivan a Mária zaznieva aj v ruskom ludovom názve „kupalského“ žltomodrého kvietka Иван-да-Марья (Melanpyrum nemorosum). K všeobecne prijímanému zisteniu, že Ivan Kupala je transformovaný Ján Krstitel’ môžeme pridat aj nové zistenie, Mária z kupalských obradov je transformovaná Mária Egyptská..

${ }_{12}$ Moravská Mařena na otázku, čo jedla počas pôstu, často odpovedá, že jedla kopřivy, zelí.

${ }^{13}$ Motív nedostatku a jeho prekonania tvoril „velkú tému“ aj v rámci základného praslovanského mýtu (Toporov, 1998).

${ }^{14}$ Zimnica sa Zosimu zmocní aj vtedy, ked’ vidí modliacu sa kajúcničku levitovat’ asi laket’ nad zemou, text teda povoluje (presnejšie priamo nezakazuje) aj z krest’anského hladiska trochu nekorektnú konkretizáciu -nadinterpretáciu typu: Mária zosiela (ovláda) choroby, zimnicu.

${ }^{15}$ Košík, do ktorého sa vyberá hlavne múka (základná surovina pri príprave eucharistického chleba), ale i maslo, vajcia, sušené ovocie na koláče „pre tú smrt“, je dôležitá a častá rekvizita v rituáloch vynášania smrti, získané produkty sa na konci rituálu obradne pripravia a účastníkmi rituálu skonzumujú, na Slovensku obvykle v dome richtára alebo v dome, kde v zime boli priadky a páračky peria.

${ }^{16}$ Latinský a anglický preklad Sofroniovej legendy hovorí o šošovici.

${ }^{17}$ Na Slovensku sa v texte vynášania smrti vyskytuje pasáž typu: „Mara naša Mara, kdes tu vodu brala, ved’ som ta ja videl, ked’s ju čarovala" (Łuczyński, 2008, s. 182). 
obyčeje políbila ${ }^{18}$ starcova ústa“ (Byzantské legendy, 2007, s. 93). Potom obidvaja prijmú „životodarnou svátost“ (pre kajúcničku je to skutočne posledná večera, ako sa dozvieme d’alej, v tú istú noc totiž zomiera - Zosima jej teda nevedomky podá viaticum ${ }^{19}$ ). Po týchto úkonoch sa svätica obráti na starca Zosimu s poslednou prosbou, žiada ho, aby budúci rok prišiel na to miesto v púšti, kde ju prvýkrát stretol. Starec jej odpovie: „Oh, kéž bych tě mohl hned ted’ následovat a věčně patřit na vzácnou tvou tvář. Ale splň aspoň jedinou prosbu starcovu a ochutnej z toho, co jsem ti zde přinesl. A př̀i těch slovech jí ukázal svůj košík. Světice se jenom konečky prstů dotkla fazolí, tři z nich si vzala a nesla je ke rtům, řkouc, že jí postačí duchovní milost, zachovávající duši člověka v čistotě" (Byzantské legendy, 2007, s. 93). Nazdávame sa, že práve táto pasáž legendy predstavuje paradigmu charakteristickej rituálnej pôstnej „hostiny“, ktorá sa nie náhodou práve na smrtnú nedelu ako súčast’ vynášania smrti praktizovala v Čechách a na Morave a na ktorú upozornil Zíbrt. Konzumovala sa vtedy tzv. „pučálka“ - vo vode napučaný (naklíčený) a na sucho upražený hrach pripravovaný za starých čias ako oblúbené pôstne jedlo a „podnes známá pochoutka, obvyklá zvláště na neděli smrtnou na Moravě a v Čechách" (Zíbrt, 1910, s. 43). So staročeskými zvykmi sa zhoduje aj „obyčej moravský, posavád uživaný, jídati na smrtnou neděli smažený hrách, pučálku. Na Zábřežsku již týden před smrtnou nedělí dèvčata prosila po dědině hrachu na pučálku: „Déte nám trochu hrachu na pučálku, budem strojit Smrt." Když se mládež z obchůdzky vrátí, jídá v tom domě, kde se smrt strojila, společně pučálku“20 (Zíbrt, 1910, s. 58).

Po skonzumovaní troch fazulí (alebo šošovíc, ak veríme viac latinskému a anglickému prekladu) svätica opät pokrižuje Jordán (teda znovu „čaruje vodu“, o čom sa zmieňujú ludové texty), vstúpi na hladinu a prejde po nej spät do púšte ${ }^{21}$. Zosimas lutuje, že sa jej neopýtal ani na jej meno

Rok nato mních odchádza v dobe pôstu opät do púšte. Tam vo vyschnutom koryte rieky nachádza mŕtvolu kajúcničky obrátenú tvárou $\mathrm{k}$ východu. ${ }^{22}$ Vedla tela je na zemi nápis: „Zde pochovej, otče Zósimo, ostatky kajícnice Marie, jež zesnula podle egyptského kalendáre v měsíci Farmufi, podle římského kalendáre v dubnu, v noci Spasitelova umučení, když byla prijala svaté svátosti“ (Byzantské legendy, 2007, s. 94). Zosima sa pokúša malým kusom dreva vykopat' hrob, ale vo vyprahnutej zemi to nedokáže. Vtedy pri mŕtvej kajúcničke zbadá leva ${ }^{23}$ lížuceho jej nohy. S nádejou, že zázračná sila mŕtvej ho ochráni, sa

\footnotetext{
${ }^{18} \mathrm{~V}$ rituáli vynášania smrti často spoluúčinkuje aj mužský protipól Moreny (na Slovensku označovaný ako Dedo, Ďatko; v Čechách a na Morave Mařák, Mařoch, Smrták,; v Polsku Marzak - humorne transformovaný Zosima?). „V obci Rózsaszentmárton dievčatá pripravili ženskú a chlapci mužskú figúru, s ktorými sa dali na cestu $z$ dvoch koncov dediny. Stretli sa uprostred dediny, kde dali ženskej a mužskej figúre pobozkat' sa " (Manga, 1956, s. 446). „Děvčata vyjdou s Mařenou z jedné strany vsi, chlapci s Mařochem z druhé strany, aby se setkali prostřed dědiny, kdež se chce Mařoch s Mařenou rozloučiti a ji políbiti“ (Zíbrt, 1893, s. 467).

${ }^{19} \mathrm{O}$ týchto dimenziách významu eucharistie ako pokrmu na cestu do večnosti v byzantskej tradícii podrobnejšie pojednáva Mojzeš (2006, s. 62-67). Eucharistia slúži totiž aj ako viaticum, čiže ako pokrm na cestu zo smrti do večného života, text teda sprostredkúva aj dalšiu dôležitú teologému: velmi názorne demonštruje a ilustruje význam prijatia eucharistie v okamihu smrti.

${ }^{20}$ Pol’ská Marzanna „gotuje groch“ (Łuczyński, 2008. s. 183).

${ }^{21}$ Práve táto pasáž jej odchodu a následnej smrti v púšti v tú istú noc mohla byt dramaticky inscenovaná hodením slamenej bábky - smrti do vody.

22 „Již Mařena leži a zubami škeři“", hovorí moravský text (Łuczyński, 2008, s. 180).

${ }^{23}$ Záver príbehu, teda „presun“ Márie do podzemia získava tak v mnohom podobnú tvárnost’ ako konfliktný praslovanský lúbostný trojuholník, popri starcovi Zosimovi sa tu objavuje zoomorfná, v princípe démonická bytost', čo má v základnom praslovanskom mýte významné paralely.
} 


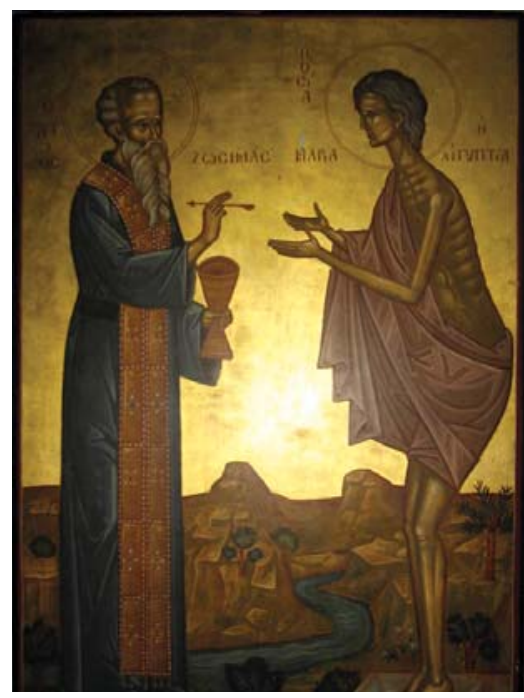

Sv. Zosima a sv. Mária Egytská - ikona z kláštora Hozeva $v$ Izraeli (zdroj: http://miriamturism.wordpress.com/2009/03/31/ sf-maria-egipteanca-in-icoane/)

Zosima k levovi obráti so slovami: „Šelmo, veliká světice přikázala pohřbít její ostatky, ale já - stařec - nemám sílu vykopat hrob. Vyhrab jej svými drápy, abychom mohli tělo světice uložit do země. “Lev ho poslúchne a starec následne pochová tělo, ktoré „bylo jako předtím nahé, oděné pouze cárem himatia, který jí Zósimás daroval" pri ich prvom stretnutí. Lev počas uloženia tela do zeme stojí nablízku, potom sa obaja rozchádzajú: „... lev odešel jako ovečka do hlubin pouště a Zósimás se vrátil zpět do kláštera“24 (Byzantské legendy, 2007, s. 95). Tu Zosima rozpovie mníchom Máriin príbeh.

Život Márie Egyptskej na dvoch prelomových miestach jej príbehu (na počiatku a konci pokánia [Obr. 1]) opakovane zarad’uje motív prijímania svätých darov - eucharistie, teda vo východnom úze kvaseného chleba a vína; pripomíname, že necelé dva týždne po Nedeli prepodobnej Márie Egyptskej na Zelený štvrtok sa slávi pamiatka ustanovenia eucharistie (Poslednej večere) Ježišom Kristom ${ }^{25}$ ). Ide o významovo nabité dominanty textu, ktoré sa, ako sa domnievame, museli dočkat' (ak naozaj máme dočinenia s transformovanou legendou ilustrujúcou zmysel eucharistie v spojitosti s významom pôstu a pokánia) a aj sa skutočne dočkali dramatického ludového stvárnenia. České a moravské textové komentáre rituálu vynášania smrti sa pravidelne zmieňujú vo veršovo ustálených formulách o zvláštnych vel'konočných koláčoch, kvasených pšeničných chleboch okrúhleho tvaru - mazancoch, pomazancoch (Zíbrt cituje desiatky dokladov, zaznamenáva aj technológiu ich prípravy, ide vždy o kvasené okrúhle koláče z bielej (pšeničnej) múky, na vrchu kto-

${ }^{24}$ Každý odchádza do svojej domény, lev do sveta oblúd a Zosima do ludského sveta, o interpretáciu podobného motívu sme sa pokúsili v inej štúdii (Golema, 2007).

${ }^{25}$ Vel'ká noc (obvyklý čas krstu nových konvertitov) poskytovala prirodzený a najdôležitejší rámec zoznámenia sa s podstatou eucharistie (chleba a vína) ustanovenej Kristom práve vo vel'konočnom čase na Zelený štvrtok, ale aj piata pôstna nedel’a pridáva vo východnej liturgii obetnému chlebu d’alšie významné symbolické dimenzie. Mária Egyptská prijatím eucharistie v chráme Jána Krstitela začína svoje pokánie v púšti, počas pokánia sa živí tromi chlebami-eulogiami, prijatím eucharistie od starca Zosimu po 47 ročnom prísnom pôste končí svoju pozemskú pút Odchádza, posilnená týmto pokrmom (a troma napučanými zrnkami šošovice?, hrachu?), do večnosti, podla skrátenej redakcie legendy v Legenda aurea jej tri obetné chleby (eulogie, teda vo východnom ponímaní plnohodnotná náhrada prosfor) dokonca vystačili ako strava na celých 47 rokov. 
rých býva nožom narezaný kríž; dodávame, že takmer rovnakou technológiou sú pripravované východné obetné chleby, tzv. prosfory, na rozdiel od západných oplátok - hostií vždy kvasené).

Staročeské mazance (nižšie sa pokúsime aj cez etymológiu názvu ukázat', že nejde o obyčajné pečivo) velmi pravdepodobne majú svoj pôvod v obradových zvyklostiach východnej cirkvi. Byzantská cirkev vždy používala pri liturgii kvasený chlieb, vychádzajúc pritom z evanjelia (v Biblii sa totiž spomína, že Kristus pri ustanovení eucharistie použil

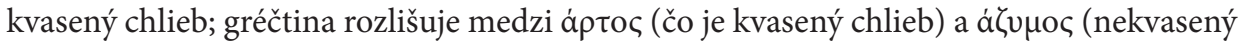
chlieb)). Pri správach o ustanovení eucharistie je v evanjeliách všade použitý termín á (Škoviera, 2007, s. 163). Ak v eucharistickom chlebe chýba kvas (teda niečo v ňom chýba), je vo východnom ponímaní neúplný. Západ počnúc od 8. storočia začal používat výlučne nekvasený chlieb. Následný (minimálne potenciálny) obradový spor okolo kvasených a nekvasených eucharistických chlebov mohol tlmene tliet' niekol'ko storočí, ${ }^{26}$ mimoriadne sa však vyostril v polovici 11. storočí a stal sa jedným $\mathrm{z}$ vážnych dôvodov schizmy v roku 1054, po ktorej v Čechách určite prestala byt birituálnost’ (teda aj kvasené chleby pri liturgii) tolerovaná.

Významný etymologicky zužitkovatel’ný argument v prospech hypotézy považujúcej mazanec za kontinuant byzantského obetného chleba (prosfory) možno nájst’ aj pri analýze najstarších významových dimenzií staročeského slova mazanec (pomazanec), v prevzatí do nemčiny aj masanze, mosanze. Slovo mazanec (velmi frekventované v českých a moravských variantoch jarného vynášania smrti) má totiž v starej češtine viacero významov, neoznačuje len druh vellkonočného pečiva, jeho význam je aj „Pomazaný (o Kristovi), česky mazaný neb mazanec" (Bělič - Kamiš - Kučera, 1978, s. 83); „Pomazanec" je v staročeštine „(člověk) pomazaný; Kristus“ (s. 209). Slovo môže mat pôvod už v staroslovien-

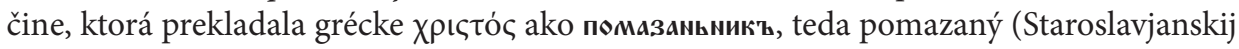
slovar, 1994, s. 474).

Možno teda ponúknut odpoved' na pri jarnom vynášaní smrti vel’mi frekventované dvojveršie-otázku typu: „Jaký je to mazanec, bez koření, bez vajec?“ Je to zludovená byzantská prosfora pevne etablovaná v birituálnych stredovekých Čechách, ktorej paralelných dobrodení sa po cirkevnej schizme lud odmietol vzdat a nad’alej ju vo velkonočnom čase pripravoval (a dodnes rovnakým spôsobom pripravuje!), označoval narezaným krížom a rituálne konzumoval $\mathrm{v}$ domácom prostredí, zároveň si ju však v chráme nechával vo vel'konočnom čase aspoň posvätit' spolu s vajcami, syrom a mäsom (Zíbrt, 1889, s. 73-75). Pripomeňme, že východná prax na rozdiel od západnej zakazovala vo Velkom pôste aj konzumáciu mlieka a vajec ${ }^{27}$, posväcovanie práve týchto produktov na konci pôs-

\footnotetext{
${ }^{26}$ Sú náznaky, že vyvolával napätie medzi byzantskou misiou a latinským franským klérom už v 9. storočí na Velkej Morave (Škoviera, 2007, 163).

${ }^{27}$ Slovenská Morena naznačuje určité nepriatel’stvo k mlieku (rozbíja hrnček s mliekom, šechtár (nádobu na dojenie) hádže o zem), dožaduje sa síce vajec, ale vajec niet, v súvislosti s ňou sa spomína kyslá pôstna bezmliečna polievka zo skvasených otrúb - slovenské „kyselo“, česká „kyselica“, pol’ský „,̇ur, żurek, mad’arské „kisze“. Krestanský Východ sa riadil Trullským snemom (692), ktorý zakazoval v pôste používat nielen mäso, ale aj vajcia a mlieko. Západ nariadenia tohto snemu neprijal, preto franskí misionári dovolovali napr. Bulharom jest' vo Vel'kom pôste pokrmy z vajec a mlieka (Škoviera, 2007, s. 168), aj preto je pozoruhodné ak sa pramene z 15. storočia zmieňujú o uhorskom zvyku zdržiavat’ sa vo velkopôstnom období nielen mäsa, ale i syra, mlieka a vajec (s. 170), ešte pozoruhodnejšie je, že rovnaký zvyk sa vyskytoval u Čechov: „... staři Čechové, rozmilí předkové naši, od vajec i ode všeho mličného pokrmu skrze celý puist chvalitebně se zdržovati obyčej měli... ", píše cirkevný spisovatel' Ferdinand Seelisko v roku 1774 (citované podla Zíbrt, 1889, s. 81).
} 
tu vo východnom obrade by teda malo svoju logiku. L’ud v chráme síce prijímal nekvasené pšeničné oblátky, doma si však neodoprel ani folklórny kontinuant prosfor - vel'konočné mazance, dávna birituálnost' sa teda premietla, uchovala a petrifikovala v rámci ludových velkonočných zvykov. Mazance sa $\mathrm{v}$ analyzovaných textoch dávali do nápadne úzkeho súvisu s Mařenou - Velikonočkou (pokriky typu „Něsemy Mařenu na poly smaženu, s vajci, pomazanci“). Druhý komponent eucharistie - víno-krv (niekedy nahradený aj pivom, pálenkou) sa $\mathrm{v}$ analyzovaných ludových textoch tiež pravidelne pripomína $\mathrm{v}$ štvorveršiach typu: „Svatý Petr z Ř́ma dal nám flaši vína, abychom se napili, Pána Boha chválili.“

K prevzatiu dialogizovanej liturgickej hry o Márii Egyptskej zbožnými laikmi, k jej úniku mimo chrám mohlo dôjsţ za dramatických okolností, ktoré nastali po cirkevnej schizme v polovici 11. storočia, po ktorej už predtým tolerovaná birituálnost’ nebola možná a Nedela prepodobnej Márie Egyptskej odrazu vypadla z liturgického kalendára západných Slovanov. Táto zmena nebola všeobecne prijatá z dôvodov, ktoré určite nastali po úplnom zákaze východnej liturgickej praxe. ${ }^{28}$ Predpokladáme, že časṫ zbožných laikov i kňazov zmenu liturgických zvyklostí neprijala (nazvime ich termínom „staroobradníci“) a nadalej mimo chrámu bez kontroly cirkevných vrchností pokračovala v starej (polo) liturgickej praxi, vo vynášaní smrti, v ritualizovanej konzumácii vel'konočných kvasených prosfor-mazancov či pučálky. Išlo totiž o sviatok, ktorý sa už pevne etabloval v kolektívnej pamäti (ako všeobecne prijatá substitúcia pravdepodobne pár storočí predtým vytlačil, absorboval, prekryl bližšie neznáme pohanské sviatky príchodu jari, rituálne podporujúce a rámcujúce koniec zimy a nástup vegetácie, rozohrávajúce vel'kú tému nedostatku a jeho prekonania). U l’udových vrstiev vzdialených od subtílnych teologických polemík nepochopitelný zákaz takéhoto dôležitého sviatku musel vyvolat úzkostnú tenziu. Sviatok teda začali slávit’ „ilegálne“, bez cirkevnej kontroly a mimo chrámu. Takýto vývoj možno predpokladat iba u tých Slovanov najprv obradovo silno ovplyvnených byzantskými misiami, neskôr istý čas birituálnych, ktorí sa po cirkevnej schizme ocitli na západnej, latinskej strane „železnej opony“, teda práve a len u Slovanov stredovekej Sclavinie. U južných a východných Slovanov používajúcich nad’alej byzantský obrad podobne načasovaný a takto rozvinutý „ludový sviatok“ nemohol vzniknút jednoducho preto, lebo východiskový text sviatku neopustil priestor chrámu a zostal (dodnes) v podobe živej liturgie inscenovaný v jeho vnútri, pod kontrolou cirkvi, nemohol sa teda kontaminovat' ani spájat' do hybridných útvarov.

Výsledkom „staroobradníckej“ iniciatívy bola postupná transformácia liturgických textov, skúsme napr. paralelne čítat', hladajúc zhody, nasledovné pasáže legendy a potom ich predpokladanú folklórnu transformáciu:

„Zósimas jí řekl: „Cožpak jsi netrpěla nedostatkem jídla a šatů?“ Ona mu odpověděla: „Když jsem snědla ty chleby, o kterých jsem Ti říkala, sedmnáct let jsem se živila trávami a vším, co jsem mohla na poušti najit“ (Byzantské legendy, 2007, s. 91). > „Cos Mařeno, cos Mařeno, cos v postě jídala? (O mila Mařeno, cos ty v postě jedla? Mořana, Mořana cos v pošč jodala? Marzanna, marzanna, coś v poście jadała? Mařéno, Mařéno, co si obědvala?) Chlyb ze slaninami miły Ponbug z nami. (Groch ze słoninami, Miły Pan Bóg z nami. Zele

\footnotetext{
${ }^{28}$ Pápežská politika po rozdelení cirkví roku 1054 v oblastiach, kde dominácia latinskej kultúry a orientácia na Rím boli jednoznačné (teda napr. v Čechách a na Morave), bola taká, že kúria neváhala potláčat akékolvek prejavy iných rítov ako bol rímsky a likvidovat akékolvek rezíduá iných kultúr, než bola latinská (Avenarius, 1992, s. 134 ).
} 
s kopřivami, hrách se slaninami, kašu s oškvarkami. Ach jidavala sem ja zelís kopřivama) (Łuczyński, 2008, s. 183).

„Himation, které jsem mněla na sobě, když jsem se prepravovala přes Jordán, se roztrhalo" (Byzantské legendy, 2007, s. 91). > „Čo ti tam dávali? Sukňu mi driapali“ (Łuczyński, 2008, s. 18); „Išla nevesta cez pole, roztrhla si sukňu na kole..."(Bednárik, 1943, s. 86).

„Zósimas jí řekl: „Kolik let, paní má, žiješ na této poušti?" Žena odpověděla: „Zdá se mi, že je to čtyřicet sedm let, co jsem opustila Svaté město. “Zósimás pravil: „Čím se živíš, má paní?"Žena řekla: „Dva a pưl chleba jsem mněla s sebou, když jsem překročila Jordán, brzy velice ztvrdly a vyschly a já je po malých dávkách snědla"Zósimás řekl: Kolik let jsi prožila zcela $v$ klidu a po kolika letech po té nenadálé přeměně jsi už necítila pokušeni??"... Po pravdě, otče, sedmnáct let jsem bojovala v této poušti se svými neskrotnými žádostmi..." (Byzantské legendy, 2007, s. 91). > „Hej Maria, hej. Maria, kaj si dluho byla?“ (Zíbrt, 1893, s. 468); „Muriena, Muriena, kde si prebývala? Marmuriena, kde si bola?"(Łuczyński, 2008, s. 181); „Три днї по милому тужила. Три хлїби ззїла“"(Łuczyński, 2008, s. 185).

Dôkazom mimoriadneho recepčného ohlasu Života Márie Egyptskej u Slovanov stredovekej Sclavinie je to, že Nedela prepodobnej Márie Egyptskej („Marmurienová nedela“ v ludovom podaní na Slovensku či „niedziela marzania“ v Pol’sku) prežila (niekedy posunutá na Kvetnú nedel’u) s príslušnými rituálmi napriek opakovaným cirkevným zákazom ako ludový sviatok do 19., dokonca miestami až do 20. a 21. storočia, kedy bola popísaná etnografmi. Títo však „zahodili klúče“ od jej interpretácie chybným apriórnym (a plošne prijímaným) predpokladom (napr. Manga, 1956), že byzantsko-slovanská etapa stredovekých dejín tzv. Sclavinie nemohla zanechat’ v ludovej kultúre také výrazné a masívne živé rezíduá.

Život kajúcničky Márie obsahuje viaceré náhodné štrukturálne podobnosti, ktoré vystúpia na povrch a stanú sa zaujímavé aj pri paralelnom čítaní tejto byzantskej legendy a dnes už čiastočne rekonštruovaného Mokošinho textu. Toporov (1998, s. 93-94) upozorňuje na vklad tzv. Mokošinho textu do „základného praslovanského mýtu“ a identifikuje viaceré jeho fragmenty: ${ }^{\star}$ Mokoš $\&{ }^{\star}$ žena $\&{ }^{\star}$ matı $\&{ }^{\star}$ děti; ${ }^{\star}$ Mokoš $\&{ }^{\star}$ ženy $\left({ }^{\star}\right.$ baby); ${ }^{\star}$ Mokoš \& ${ }^{\star}$ zemja; ${ }^{\star}$ Mokoš \& nizь \& ${ }^{\star}$ bolto no i ${ }^{\star}$ vrchъ; ${ }^{\star}$ Mokoš $\&{ }^{\star}$ voda $\left({ }^{\star}\right.$ mokrъ) no i ${ }^{\star}$ Mokoš \& ognь; ${ }^{\star}$ Mokoš \& ${ }^{\star}$ vъlna $\left({ }^{\star}\right.$ sьrstь $) \&{ }^{\star}$ ovbca; a tiež ${ }^{\star}$ Perunъ \& ${ }^{\star}$ gъnati (žęti) \& ${ }^{\star}$ děti ( ${ }^{\star}$ Mokoš).

Mokoš ako slovanský kontinuant trojmocnej indoeurópskej bohyne-rieky (kompetentná pravdepodobne vo všetkých troch starých indoeurópskych funkciách: mágie a práva, vojny, plodnosti; v zachovaných fragmentoch sa však akcentuje hlavne funkcia plodnosti) účinkuje ako jediná ženská postava „základného praslovanského mýtu“, v rámci zvláštneho „mileneckého trojuholníka“ (Toporov, 1998, s. 88). Vo fragmentoch jej mýtu je zaznamenaná trestuhodná blízkost’ Mokoši a Velesa, za ktorú boli potrestaní Hromobijcom, to odkazuje na dve etapy jej ženského osudu ( ${ }^{\star}$ Mokoš \& ${ }^{\star}$ Perunъ $-{ }^{\star}$ Mokoš \& Velesъ), ktoré našli ohlas $\mathrm{v}$ rozšírenom sujete. $\mathrm{V}$ ňom žena pohybujúca sa $\mathrm{v}$ komplikovanom lúbostnom trojuholníku poruší akýsi zákaz a tažko za to zaplatí (Toporov, 1998, s. 91). Mokoš u Rusov je predstavovaná ako žena s vel'kou hlavou a dlhými rukami pradúca po nociach (Toporov, 1998, s. 89), je spojená s podzemím, mokrotou, vlahou, vodou, temnotou, nocou, s ovčou vlnou a s priadzou. Svedectvá o nej u iných Slovanov sú minimál- 
ne, dá sa to vysvetlit tým, že bola takmer bezo zvyšku pomerne rýchlo a bezproblémovo christianizovaná, $\mathrm{k}$ čomu mohlo dôjsţ vtedy, ak misionári našli a umne využili náhodné zhody pohanských a krestanských textov (byzantskí misionári boli vdaka odlišnej textovej tradícii v zrejmej výhode) a existujúci kult bez príliš radikálnych zásahov len presmerovali a podelili medzi kompetenčne príbuzné svätice. Vela tu naznačuje Toporovov súpis neskorších transformácií Mokoši fungujúcich v charakteristických príbehoch pod menami: „иарииа Маланьииа, Маланья, св. Пятнииа, Параскева Пятнии,а, св. Анастасия, Мара, Марена, Морана, Марина, Мария“ (Toporov, 1998, s. 97), posledné mená sme cielene zvýraznili. U Mokoši sú podčiarknuté sexuálne atribúty: vel'ké prsia, dlhé rozpustené vlasy, indície ukazujú aj na súvislost’ s nemravnými ženami (slovo мокосья v ruských dialektoch funguje ako označenie nemravnej ženy). Mokoš je zároveň ochrankyňa rodičiek, riadi pôrody (túto kompetenciu, nezlučitelnú s kompetenciami sv. Márie Egyptskej, mohla po nej prevziat sv. Marina/Margita Antiochijská). Mokoš je matka a zároveň neverná žena. V jej deň (u východných Slovanov je to obvykle piatok, pretože výraznú čast' jej kompetencií absorbovala aj sv. Paraskeva - Piatnica), platí zákaz niektorých ženských prác, napr. prat prádlo a hlavne ho vyvárat' (rozohráva sa tu téma ohňa a vody) či zákaz priast'. Mokoš je trestaná ohňom, možno preto, podotýka Toporov, že voda je súzvučná s jej podstatou, a preto nie je pre Mokoš nebezpečná (Toporov, 1998, s. 89-93). Spomeňme si v tejto súvislosti na Máriu Egyptskú, kráčajúcu po vode, no sužovanú v púšti pálavou a smädom, spálenú do čierna; či na kupalský kvietok Иван-да-Марья [Obr. 2], kde Ivana (sv. Jána) symbolizuje žltá farba ohňa a Máriu modrá farba vody (Toporov, 1998, s.127, 159, 162); náhodných štrukturálnych zhôd je tu teda skutočne dost'. Varianty mena krestanských transformácií Mokoši typu Mara, Mária odkazujú, nazdávame sa, na sv. Máriu Egyptskú $^{29}$; varianty mena typu Mařena (Morava), Morena (Slovensko), Marzana (Polsko) odkazujú už na inú sväticu, patrónku rodičiek a ochrankyňu pri pôrodoch, martýrku a pannu sv. Marinu/Margitu Antiochijskú. Fragmenty legendového textu práve tejto martýrky sú, podla nášho názoru, tiež prítomné v textoch vynášania smrti, (nedokážeme zatial’ nájsț ich liturgickú oporu ${ }^{30}$, sviatok tejto martýrky je v liturgickom kalendári zaradený totiž až v čase žatvy, v júli).

\footnotetext{
${ }^{29}$ Bálint (online) vyslovuje podozrenie, že miestne názvy obcí typu Szentmária v stredovekom Uhorsku boli dané pôvodne nie na počest' Kristovej matky panny Márie (tá sa v mad’arských prameňoch a miestnych názvoch označuje štandardne ako Boldogaszony - Štastná žena), ale na počest’ kajúcničky Márie Egyptskej. V Bálintovom zozname „podozrivých lokalít“ sa objavuje viacero lokalít aj zo Slovenska: Liptószentmária (slovenský názov Svätá Mara), Szentmária v Turci (dnes Socovce, v minulosti Svätá Mara), ale napr. i Somorja (slovensky Šamorín). Patrocínium sa vyskytovalo na krakovskom Waweli, kde bola kaplnka „św. Marii Egypcjanki.“

${ }^{30}$ Stredoveká dráma odvodená z liturgie však nerešpektuje povestné tri pravidlá o jednotách, nezachováva ani jednotu miesta (dej sa posúva z raja na zem, zo zeme do pekiel atd.), ani jednotu času (dej niekedy zachytáva tisícročné rozpätia) „ba ani jednotu deja, najzákladnejšiu zo všetkých, pretože zväčša nedbá na to, aby postupné činy dramatických postáv boli spojené a navzájom odôvodnené, postačí jej plynulost' a súvislost' teologických a mystických významov" (Černý, 1964, s. 33) syntagmaticky pospájaných napr. v zhode s misijnými cielmi. Pre stredovekú drámu je typická tendencia $\mathrm{k}$ akémusi narastaniu nových a nových pupeňov, tendencia rozširovat' pôvodnú verziu hry na jej začiatku a konci o výjavy d’alšie a dalšie, „sklon spojovat sa do celých sériových radov hier, ktoré sa uvádzajú spolu a súvisle“(s. 37). Dramatické jadro „obrastá“ stále dalšími výjavmi, často dochádza k „pretučneniu hier“ (s. 99), pridávaniu d’alších epizód, postáv, legendových látok. Výsledkom je „duženie, prerábanie, kríženie, invázia prvkov humoru“ (s. 104). Výsledky týchto procesov nás dnes dost̉ mätú a sme v rozpakoch, ked’ máme predpokladat liturgický pôvod pri texte obsahujúcom v ludovom podaní bežne aj obscénne či vulgárne pasáže, časté napr. aj v textoch jarného vynášania smrti.
} 


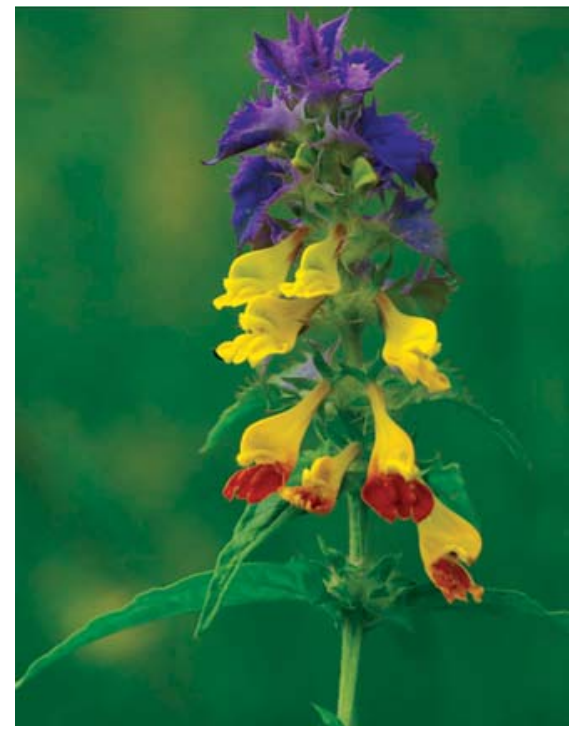

Melampyrum nemorosum - ruské názvy kvietku sú Иванда-Марья,; ukrajinské іван-і-марія, день-і-ніч (foto: Ing. Vladimír Nejeschleba, zdroj: http://www.nahuby.sk/obrazok_ detail.php?obrazok_id=110613ernext_img_type=gallery )

Domnievame sa, že verzie mena topenej a spal’ovanej slamenej bábky Mařena (Morava), Marzana (južné Pol’sko), Morena, Marena, Marina (Slovensko, severné Madarsko), Marina (západná Ukrajina) sú bez interpretačného násilia výborne vysvetlitelné z gr. Mapiva (Marina), čo je východný variant mena sv. Margity, patrónky rodičiek, ktorú napr. pravoslávni Rusi uctievajú dodnes pod menom Святая великомученица Марина (Маргарита), západná cirkev jej kult v r. 1969 zrušila. Celý text jarného „vynášania smrti“ (uchovaný v množstve variantov rozosiatych hlavne po celej ploche bývalej stredovekej „Sclavinie“) odkazuje potom na niekolko zdrojov, nielen na praslovanskú textovú tradíciu, ale predovšetkým na dramaticky stvárnenú legendu kajúcničky Márie Egyptskej, ${ }^{31}$ ktorá bola doplnená a neskôr zmiešaná s neznámou (hypotetickou, rekonštruovatelnou) „martýrskou hrou“ o sv. Margite (Marine) Antiochijskej. Takto koadaptovaný archetyp (ludová pamät si totiž nepamätá individuálne, ale len exemplárne) musel byt’ zo špecificky mytologických dôvodov mimoriadne populárny u Slovanov, medzi ktorých sa kult oboch svätíc dostal byzantským sprostredkovaním v ranej fáze christianizácie (indikujú to, okrem množstva d’alších indícií, aj varianty mena typu Mařena, Marinka, Morena, Marzyana ako kontinuanty a adaptácie gréckeho (Aүía) Mapiva/(svätá) Marina). Súbežný výskyt grécko-slovanského a latinského variantu mena tejto svätej v tom istom priestore vo variantoch rovnakého textu (v Čechách sa pri vynášaní smrti pravidelne obracajú aj na sv. Markétu, na Morave na Mařenu) odkazuje na birituálne prostredie, a teda nepriamo indikuje dobu vzniku a rozvoja rituálu, v ktorej mohla byt birituálnost' tolerovaná (9. - 11 . storočie, teda Velká Morava a jej v kultúrnom zmysle následnícke štáty - přemyslovské Čechy, piastovké Pol’sko a arpádovské Uhorsko). Nie je náhodné, že hranice výskytu tohto zvyku sa vo výraznej miere kryjú s hranicami týchto stredovekých štátnych útvarov.

${ }^{31}$ Byzantská liturgia poznala ludové scénky, krátke epizódy upravené do scénických dialógov oživujúce kázanie rytmickým deklamovaním a spevom, teda malé dramatické útvary slúžiace k oživeniu liturgie (Hrochová Tůma, 1991, s. 143). 
Staroslovienska Molitva na diavola (Konzal, 2002, online), ktorá sa dostala na Kyjevskú Rus z Čiech niekedy v 12. storočí, prosí skupinu svätíc, do ktorej patrí sv. Lucia, Felicita, Valpurga, ale aj „...марнна.маргарtта...“" (teda Marina/Margareta), nevieme rozhodnút, či táto nie náhodná následnost̉ odráža ešte uvedomovanú ekvivalenciu mien v birituálnom prostredí alebo už prípadné „rozdvojenie“ obrazu mučeníčky, ktoré predchádzalo, ako prechodná fáza v Čechách, odkial’ modlitba pochádza, neskoršiemu preradeniu Mariny do kategórie pohanských bohýñ).

O moravskej Mařene a jej predpokladanej spojitosti so sv. Margitou, patrónkou rodiacich žien (a aj o jej preklasifikovaní na pohanskú bohyňu), niečo zásadné vypovedá podstatne mladší text s názvom Staré paměti kutnohorské (1675): „Hora pak Kutná tím se honositi může, že se nikdy slepým, němým, hluchým a od lidí dělaným modlám neklaněla. Nikda domácích šetkư, skř́tků, a diblikư nechovala, jim nekouřila. Nikda ani v moru Tř́bka, ani v hladu Živěny, ani v dešti Pohody, ani v suchotě Mokrosly, ani při ženském porodu Mařeny, ani v neplodnosti Zizlily nevzývala“ (citované podla Zíbrt, 1889, s. 200). Autor textu už vníma Mařenu (východnú obdobu sv. Margity?) ako pohanskú bohyňu, povedomie, že ide o variantné pomenovanie sv. Margity, zachované ešte v Molitve na diavola, sa, zdá sa, už vytratilo, kompetencia ochrankyne rodiacich žien ale zostala.

Ďalšiu pridruženú a z krestanského textového materiálu už tažko vysvetlitelnú kompetenciu „pohanskej bohyne“ Marzanny dokumentuje krakovský kanonik Dlugosz (1415-1480), ked' kompetenčne identifikuje pol'skú Marzannu s rímskou Ceres (bohyňou rolníctva a darkyňou polnohospodárskych plodín) ${ }^{32}$. Paralelne s Marzannou spomína ešte dalšiu pol’skú pohanskú bohyňu Dziewannu,, ktorú interpretuje ako rímsku Dianu, Poliakmi vraj považovanú zároveň za nevestu a matku, vládkyňu lesov a hájov. $\mathrm{Na}$ inom mieste sa Dlugosz zmieňuje o jarnom zvyku topit” „Dziewannu a Marzannu“, z čoho podla Gieysztora (1986, s. 145-149) plynie, že Dziewanna nebola samostatná bohyňa, iba variantný (sezónny?) názov Marzanny. Táto dvojnost' v jej príbehu (pole/les; ludský svet/ ne-ludský svet), ktorý Dlugosz chybne rozdelil medzi dve osoby, navyše naznačuje dve radikálne odlišné fázy ženského osudu, o ktorých už bola reč.

Nápadne častá prítomnost' (vzývanie) sv. Markéty, sv. Markity („klíčnice z nebe“) $\mathrm{v}$ českých variantoch textu vynášania smrti nebola doteraz povšimnutá ani interpretačne využitá. Desiatky podobných textov vynášania smrti obracajúcich sa na sv. Markytu, Markétu z rôznych lokalít v Čechách cituje Zíbrt (1889, 1893, 1910). Markita nie je síce v zachovaných českých verziách textu priamo stotožňovaná s topenou bábkou, tým sa líši od „archaickejšej“ a démonickejšej, ale, ako sa domnievame, čiastočne ekvivalentnej moravskej Mařeny, slovenskej Moreny či polskej Marzany. Moravská Mařena, pol’ská Marzana i slovenská Morena je stínaná, smažená na oleji (kontaminácia s legendovou látkou o sv. Dorote alebo význam oleja v čase pôstu?), roztrhaná, bitá, hodená do vody, chladená vodou, púštaná do vody, topená, pochovávaná do zeme; všetky úkony majú analógie $\mathrm{v}$ oficiálnej legende sv. Margity Antiochijskej - pálenie faklami, trhanie tela trojzubcami, topenie v sude $s$ vriacou vodou, statie (Gerát, 2002; Here followeth the glorious Life... Martyr S. Margaret, online). Slovenské fragmenty textu typu: „Morena, Morena, za kohos umrela? Nie za nás, nie za nás, ale za utláčaných krestanov“, odkazujú, nazdávame sa, tiež na martýrsku smrt'. Textové fragmenty z Mad’arska odkazujú zase na súd („Tavo,

${ }^{32} \mathrm{~V}$ českých verziách textu vynášania smrti sa tiež vel’mi frekventovane objavuje štvorveršie typu: „A ty, svatá Markito, dej nám pozor na žito, na to všecko obilí, co nám Pán Bůh nadělí.“ 
kysel” (= Morena), tavo, na peštianskuo (d’armotskô, sarvašskô) právo“), atribúty ako veniec odkazujú k mučeníckej korune; spojitost’ s niektorými pôstnymi jedlami, s riekou, s umývaním a pradením odkazuje zase k sv. Márii Egyptskej.

Naša hypotéza o pravdepodobnom zlúčení dvoch svätíc a pohanskej praslovanskej bohyne do jedného archetypu (za špecifických historických podmienok a na vymedzenom území) rieši novým spôsobom ešte jeden vážny problém, a to sú zdvojené formy mena topenej slamenej bábky typu Marmuriena, Marmariena, Mamurienda vyskytujúce sa na Slovensku. Tieto formy so zdvojením Ma(r)-muriena boli dávané do súvislosti s rímskym Marsom, majúcim aj agrárne funkcie, ktorého starolatinské mená boli aj Marmor, Mamers, a tiež s rímskym zvykom vyháňania starého Marsa (Mamurius Veturius) dňa 14. marca (Ivanov - Toporov, 1987, s. 111). Ponúkame iné vysvetlenie, treba radšej rozpliest' archetyp, oddelit komponent Mara (Mária) a Muriena (Marina), čiže z Marmurieny spätne urobit Máriu a Murienu, treba teda vnímat meno typu Marmuriena ako kompozitum, stopu textových transformácií (touto operáciou sa napr. z „Marmurienovej nedele“ stane nedela Márie a Mariny). Podobne vzniknuté kompozitum je časté napr. v ukrajinskej tradícii, kde v ludovom podaní vystupujú sv. Kosmas a Damián dost̉ často ako jedna osoba pod menom Kuzmodemjan. Obidve svätice sa mohli stretnút a následne splynút do jednej postavy práve na takéto stretnutie vhodnej staršej ploche Mokošinho textu.

$\mathrm{V}$ analyzovaných textoch máme dočinenia s priamo paradigmatickým prípadom, ked' na seba navrstvené krestanské významy prevrstvili pohanské bez toho, aby ich vymazali a výsledok „musí byt ćítaný ako palimpsest“ (Burke 2001, s. 205). Misionári totiž museli primät ku konverzii nielen jednotlivých Slovanov, ale, aby im túto konverziu ulahčili, aj niektoré z ich oblúbených (a na to vhodných) príbehov. Život Márie Egyptskej však nezakryl celú plochu Mokošinho textu, zvyšné, vytŕčajúce plochy z misijných dôvodov nemohli ostat obnažené, prekryla ich preto dalšia na to vhodná legenda martýrky a (na rozdiel od Márie Egyptskej) panny Mariny/Margity Antiochijskej, ochrankyne rodičiek (v praslovanskom texte mala túto dôležitú kompetenciu Mokoš a tú po nej z pochopitelných dôvodov nemohla prevziat' Mária Egyptská, nemalo by to žiadnu oporu v jej hagiografii).

Naše tu prezentované čítanie textov jarného vynášania smrti vychádza z predpokladu, že čítame neskorú zludovenú verziu dvoch na seba uložených legiend, značne pozmenenú, kontaminovanú pohanskými motívmi, ktorú možno opísat ako výsledok transformačných postupov, ako pretavenie či znetvorenie východiskového textu. Naše čítanie chcelo byt' „opakovatelným pokusem rozpoznat ve struktuře textu stopy, vzpruhy, vrstvení, dutiny a vruby, které po sebe zanechala trasnsformace" (Lachmann, 2002, s. 52). Takto chcelo upozornit na viaceré dôležité zabudnuté staré textové fólie, ktorá ležia pod novším, až v 19. a 20. storočí písomne zachyteným folklórnym podaním. Ak sa toto paralelné čítanie osvedčí (naša štúdia je iba prvý krok), umožní to aj presnejšie objasnenie tých motívov praslovanskej mytológie, ktoré sa v tomto „hybridnom“ textovom útvare ukryli, no určite nie v takej rýdzosti, akú predpokladali predchádzajúce výskumy postulujúce, že Morena je slovanská bohyňa smrti odvoditel'ná v princípe a takmer v celku z praslovanského mytologického dedičstva. 


\section{Literatúra}

Avenarius, A.: Byzantská kultúra v slovanskom prostredí v VI. - XII. storočí. Bratislava: VEDA, 1992.

Bálint, S.: Ünnepi kalendárium 1. Április 2. Budapest : Szent István Társulat, 1977. [online, citované 2009-05-01]. Dostupné z WWW: < http://mek.niif.hu/04600/04656/html/ unnepiki0063/unnepiki0063.html>

Bednárik, R. et al.: Slovenská vlastiveda II, Bratislava : SAVU, 1943.

Bělič, J. - Kamiš, A. - Kučera, K.: Malý staročeský slovník. Praha : SPN, 1978.

Bosák, R. - Bosák, M.: Zvyky a tradície na Slovensku. Prešov, 2006.

Burke, P. : Lidová kultura v raně novověké Evropě. Praha Argo, 2001.

Byzantské legendy. Výběr textů ze IV. - XII. století. Přeložili Emilie Bláhová, Zoe Hauptová, Václav Konzal, Ilona Páclová. Červený Kostelec : Pavel Mervart, 2007.

Černý, V.: Stredoveká dráma. Bratislava : SVKL, 1964.

Dvorník, F.: Byzantské misie u Slovanů. Praha : Vyšehrad, 1970.

Dvorník, F.: Zrod střední a východní Evropy. Mezi Byzancí a Ř́mem. Praha: Prostor, 2008.

Eftychiadis, A. C. - Marketos, S. G.: Saint Marina: The Protectress of Nephrology. In: American Journal of Nephrology, roč. 19, 1999, s. 107-110.

Frazer, J. G.: Zlatá ratolest. Praha : Mladá fronta, 1994.

Gerát, I.: Život svätej Margity v stredovekej mal'be na Slovensku. In Pamiatky a múzeá, 2002, č. 3, s. 43-47.

Gieysztor, A.: Mitologia Slowian. Warszawa : Wydawnictwa Artystyczne i Filmowe, 1986.

Golema, M.: Medieval Saint Ploughmen and Pagan Slavic Mythology. In: Studia mythologica Slavica X, 2007, s. 155-177.

Golema, M.: Svätý Blažej ako „vlčí pastier“v textovej tradícii z českého, slovenského a madarského prostredia. In: Studia mythologica Slavica XI, 2008, s. 147-173.

Grimm, J.: Deutsche mythologie. II Band. Graz : Akademische druck- u. VERLAGSANSTALT, 1968.

Here beginneth the life of Mary of Egypt. In: Medieval Sourcebook: The Golden Legend (Aurea Legenda). Compiled by Jacobus de Voragine, 1275, Englished by William Caxton, 1483, [online, citované 2009-04-07]. Dostupné z WWW: <http://www. fordham.edu/halsall/basis/goldenlegend/GoldenLegend-Volume3.htm\#Mary\%20 of\%20Egypt>

Here followeth the glorious Life and passion of the Blessed Virgin and Martyr S. Margaret, and first of her name. In: Medieval Sourcebook: The Golden Legend (Aurea Legenda). Compiled by Jacobus de Voragine, 1275, Englished by William Caxton, 1483, [online, citované 2009-04-07]. Dostupné z WWW: <http://www.fordham.edu/halsall/basis/goldenlegend/GoldenLegend-Volume4.htm\#Margare>

Horváthová, E.: Rok vo zvykoch nášho ludu. Bratislava : Tatran, 1986.

Hrochová, V. - Tůma, O.: Byzantská společnost (Soubor byzantských reálií). Praha: Karolinum, 1991.

Hurtajová, Z.: Legendy staršej medzinárodnej proveniencie v knižkách ludového čítania na Slovensku a dimenzie ich „outsiderstva“. In: Človek z okraja uprostred literatúry. Banská Bystrica : Fakulta humanitných vied Univerzity Mateja Bela, 2007, s.58-69. 
Ivanov - Toporov, Иванов В. В. - Топоров В. Н.: Иследоваия в области славянских древностей. Москва : Наука, 1974.

Ivanov - Toporov, Иванов В. В. - Топоров В. Н.: Марена, Марана, Морена, Маржана, Маржена. In: Мифы народов мира 2. Москва : Советская энциклопедия, 1988, s. 111.

Ivanov - Toporov, Иванов В. В. - Топоров В. Н.: Мокошь. In: Мифы народов мира 2. Москва : Советская энциклопедия, 1988, s. 169.

Jančovič, I.: Tematizáci outsiderstva v prozaickom texte a možnosti jej literárnovedného výskumu. In: Človek z okraja uprostred literatúry. Banská Bystrica : Fakulta humanitných vied Univerzity Mateja Bela, 2007, s. 7-57.

Konzal, Конзал, В.: Старославянская молитва против дьявола. Москва: Индрик, 2002, s. 111, [online, citované 2009-03-02]. Dostupné z WWW: <http://www.krotov.info/acts/11/komnina/mol_diav.html>

Koprda, P.: Les communautés interlittéraires dalmate, slave sud-occidentale et méditerranéenne dans la période du Moyen Age et Renaissance comme les éléments décisifs dans le développement de la littérature slovaque. In: Literatúry ako súčast’ medziliterárnych spoločenstiev. Zostavil Pavol Koprda. Nitra : Katedra romanistiky Filozofickej fakulty Univerzity Konštantína Filozofa, 2003, s. 69-79.

Kožiak, R.: Cyrilometodské misie a počiatky krestanstva v Pol’sku. [online, citované 200905-01]. Dostupné z WWW: <http://www.fhv.umb.sk/app/user.php?user=koziak\&ID $=28>$

Kožiak, R.: Christianizácia Avarov a Slovanov na strednom Dunaji: príbeh svätcov-misionárov, svätá vojna alebo kultúrny šok? [online, citované 2009-05-01]. Dostupné z WWW: <http://www.fhv.umb.sk/app/user.php?user=koziak\&ID=39>

Kožiak, R.: Misionári, gentes a christianizácia. In: Annales Academiae Paedagogicae Cracoviensis : Studia Historica VI., 2007. roč. 43, č. 6, s. 11-31.

Krupa, O.: Kalendárne obyčaje III. Békéšska Čaba : Slovenský výskumný ústav, 1998.

Lachmann, R.: Memoria fantastica. Praha : Herrmann a synové, 2002.

Legenda na dzień św. Marii Egypcjanki. In: VORAGINE, Jakub de: Złota legenda. Wybór (Tłumaczyla z języka latinskiego Janina Pleziowa). Warszawa: Instytut wydawniczy PAX, 1983, s. 201-206.

Legendy stredovekého Slovenska (vybral, zostavil, poznámkami, komentármi a registrom doplnil a úvodnú štúdiu napísal Richard Marsina). Budmerice: Rak, 1997.

Life of St. Mary of Egypt. In: Holy Women of Byzantium: Ten Saints' Lives in English Translation. [online, citované 2009-03-02]. Dostupné z WWW: <http://www.fordham. edu/halsall/sbook1c.html>

Łuczyński, M.: Kognitywna definicja Marzanny - Próba rekonstrukcji fragmentu tradycyjnego obrazu świata Słowian. In Studia mythologica Slavica XI, 2008, s. 173197.

Manga, J.: Morena a jej mad’arské obmeny. In: Slovenský národopis, roč. IV., 1956, č. 4-5, s. 421-454.

Marinčák, Š.: Slovanská liturgia - liturgické dedičstvo byzantskej misie z 9. storočia. In: Slavica Slovaca, 2005, roč. 40, č. 1, s. 34-62.

Milko, P.: Služba Velkého kánonu sv. Ondřeje Krétského z perspektivy hesychazmu. In: ANNALES HISTORICI PREŠOVIENSIS ANNO 2005. Zostavili Martin Pekár, Patrik Derfiňák, Peter Zmátlo. Prešov : UNIVERSUM, 2005, s. 43-66. 
Mojzeš, M.: Eucharistia pre život večný v byzantskej tradícii. In: Studia theologica 8 , č. 3 (25), podzim 2006, s. 62-72.

Montanari, M.: Stravování. In. Le Goff, J. - Schmitt J.-C.: Encyklopedie středověku. Praha: Vyšehrad, 2002, s. 720-728.

Múcska, V: Uhorsko a cirkevné reformy 10. a 11. storočia. Bratislava : Stimul, 2004

Olexák, P.: Matky púšte. In: Ružomberský historický zborník I. Zostavil Peter Zmátlo, Ružomberok : Filozofická fakulta Katolíckej univerzity, 2007, 51-81.

Pomfyová, B.: Liturgický kontext ranostredovekej architektúry. In: ARS, roč. 38, 2005, č. 2, s. $108-134$.

Rapp, F.: Církev a náboženský život západu na sklonku středověku. Brno : CDK, 1996.

Slivka, M.: Slovenské ludové divadlo I. Genéza a vývoj hier. Bratislava : VŠMU, 1992.

Staroslavjanskij slovar, Старославянский словарь (по рукописям X-XI веков). Под редакцией Р. М. Цейтлин, Р. Вечерки и Э. Благовой. Москва : Руский язык, 1994.

Škoviera, A.: Obradové spory medzi byzantskou a latinskou misiou na Vel'kej Morave. In: Cyrilské a latinské pamiatky v byzantsko-slovanskom obradovom prostredí na Slovensku. Ved. redaktor doc. PhDr. Peter Žeňuch, PhD. Bratislava : Slavistický ústav Jána Stanislava SAV, Slovenský komitét slavistov, 2007, s. 129-171.

Škoviera, A.: Tretí slovanský život Nauma Ochridského a dátum vyhnania Metodových žiakov. In: Slavica Slovaca, roč. 42, 2007, č. 2, s. 111-123.

Švagrovský, Š.: Grécko-byzantský rítus na území Slovenska. In: Slavica Slovaca, roč. 33, 1998, č. 2, s. 97-108.

Tolstaja, Толстая C. М.: Вариативность формальной структуры обряда (Купала и Марена). In: Фольклор и постфольклор: структура, типология, семиотика [online, citované 2009-03-02]. Dostupné z WWW: <http://www.ruthenia.ru/folklore/tolstaya2.htm>

Toporov, Топоров, В. Н.: Предистория литературы у славян: Опыт реконструкции: Введение к курсу истории славянских литератур. Москва: Российский государственный гуманитарный университет, 1998

Triodion und Pentekostarion nach slavischen Handschriften des 11. - 14. Jahrhunderts. Teil I: Vorfastenzeit. Mit einer Einführung zur Geschichte des slavischen Triodions von M. A. Momina. Herausgegeben von M. A. Momina und N. Trunte. Paderborn, München, Wien, Zürich : Verlag Ferdinand Schöningh, 2004.

Turčan, V. et al.: Byzantská kultúra a Slovensko. Bratislava : Slovenské národné múzeum Archeologické múzeum, 2007.

Vel'ký kajúci kánon svätého Andreja Krétskeho. [online, citované 2009-05-01]. Dostupné z WWW: <http://www.grkat.nfo.sk/Texty/index.html>

Vita Sanctae Mariae Egyptiacae. In: The Legend of Mary of Egypt in Medieval Insular Hagiography. Edited by Erich Poppe \& Bianca Ross. Dublin : Four Courts Press, 1996, s. 51-99.

Zíbrt, Č.: Staročeské umení kuchařské. Praha : Nákladem „Staré gardy mistrů kuchařů, 1927.

Zíbrt, Č.: Staročeské výroční obyčeje, pověry, slavnosti a zábavy prostonárodní. Praha: Tiskem a nákladem Jos. R. Vilímka, 1889.

Zíbrt, Č.: Veselé chvíle v životě lidu českého. Smrt nesem ze vsi ... pomlázka se čepejří. Sv. III. Praha 1910. 
Zíbrt, Č.: Vynášení „smrti“ a jeho výklady, starší i novější. In: Český lid, 1893, roč. 2, s. 453-472.

Zilynskyj, O.: Jarní hra na Dunaj (Heličku) a její východoslovanské obdoby. In: Slovenský národopis IX, č. 4, 1961, s. 610-627.

Christian Hagiographies (The Life of Mary of Egypt, the Life of Marjeta/Marina of Antioch) and Texts on the So-Called Spring Taking away the Death (Morena) among West Slavs. An Attempt at Parallel Reading

\section{Martin Golema}

The study builds on research and interpretation of texts of so called "death (Morena, Mařena, Marzana) carrying-out in spring" among the western Slavs. The author tries to examine an assumption about the existence of a "chemically almost pure" Slavonic mythology goddess embodying death in texts about death carrying-out in spring. He tries to prove that it is a hybrid text unit originating in several text traditions, both in the identified Christian (Byzantine) text store and in early Slavonic myths.

The author also tries to show that a mythological character Morena (Mařena, Marzana) absorbed and collected the still identified text material, very likely originated in official legends about the confessant St. Mary of Egypt and about the martyr St. Margita/ Marina of Antiochia; the texts also include significant residues of so-called Mokos's text (both saints could meet and merge into a shared archetype - the early Slavonic Mokos's text was a suitable older place for this meeting). Parallel reading of legends and texts of death carrying-out in spring has brought us to the following conclusion: Acceptance of a dialogical liturgical play about Mary of Egypt (and Margita/Marina of Antiochia) by religious laymen and its leaking outside a temple probably happened under dramatic circumstances after the church schism in the middle of the 11th century. After this schism biritualism, tolerated before, was not allowed and the Sunday of St. Mary of Egypt suddenly disappeared from the West Slavs' liturgical calendar. This development can be assumed only among the Slavs, who were first ritually strongly influenced by Byzantine missions; later they were for some time bi-ritual, and after the church schism in 1054 they were left in the west, Latin part of "the iron curtain", thus exactly and only among the Slavs of medieval Sclavinia.

A proof of the extraordinary response of legends mentioned before among the Slavs of medieval Sclavinia (explained by random and missionary usable connections with Mokos's text) is the fact that the Sunday of St. Mary of Egypt ("Marmurien Sunday" in a folk tradition in Slovakia as well as "niedziela marzania" in Poland) lasted with relevant rituals - despite repeated church restrictions - as a folk element until the $19^{\text {th }}$, somethimes even the 20th and 21st centuries. 